Tadeusz Kamiński

Uniwersytet Kardynała Stefana

Wyszyńskiego w Warszawie
Etyka pracy socjalnej w filozofii spotkania i dialogu, red. M. Duda, I. Rybka, H. Kaszyński, Kraków 2017, s. 71-83

(Praca Socjalna w Teorii i Działaniu, 4).

DOI: http://dx.doi.org/10.15633/9788374386425.06

\title{
Praca socjalna i działalność charytatywna - wspólna droga do człowieka w potrzebie
}

\author{
Social work and charitable activity - the common way \\ to a people in need
}

\begin{abstract}
Abstrakt: Praca socjalna jako profesjonalna działalność pomocowa wyrosła $\mathrm{z}$ bardzo długiej tradycji pomagania zakorzenionej w inspiracjach duchowych/ religijnych, sięgających odległej starożytności. Szczególną postać instytucjonalną działalność ta przybrała wraz z pojawieniem się chrześcijaństwa i idei caritas jako czynnej miłości bliźniego. Po wiekach swoistego monopolu religijnej filantropii pojawiła się zawodowa praca socjalna, wykonywana przez wykwalifikowany personel wyspecjalizowanych instytucji działających w oparciu o dość szczegółowe przepisy i normy funkcjonowania. Spowodowało to - w mniejszym lub większym stopniu - scedowanie na państwo odpowiedzialności za los ludzi w potrzebie. Niewątpliwie jednak
\end{abstract}

Abstract: Social work as a helping profession has a long history, that is strongly linked to religious inspiration. For centuries, such activity has been practiced by parishes, religious orders and individual philanthropists. At the end of the 19th century social work appeared as a professional activity. Specialized help institutions were created and developed, but charitable activity is still necessary at all. Both forms of aid have not only a common history. Charitable activity and social work have the same target groups and use similar methods. In the last over twenty five years the charitable activity in Poland has changed considerably. It can respond quickly to changes in operating conditions and emerging new problems and seek innovative ways 
działalność charytatywna nie straciła na znaczeniu i w istotny sposób uzupełnia pracę służb społecznych. Obie te formy działania łączy bowiem nie tylko wspólna historia czy podobieństwo metod, ale zwłaszcza cel i zakres: niesienie wsparcia osobom potrzebującym, niezaradnym życiowo, zagubionym. Działalność charytatywna bardzo zmieniła swoje oblicze. Potrafi szybko reagować na zmiany warunków działania i pojawiające się nowe problemy oraz poszukiwać innowacyjnych metod pomagania. Zarówno zawodowa praca socjalna, jak i działalność charytatywna kroczą wspólną drogą do człowieka w potrzebie, są sprzymierzeńcami w dobrym dziele.

Słowa kluczowe: praca socjalna, działalność charytatywna, miłosierdzie, caritas. of helping. Thus, social work and charitable activity walk the common way to a people in need. They are allies in this mission.

Keywords: social work, charitable activity, charity, caritas.

Praca socjalna w takiej postaci, jaką znamy obecnie, a więc jako profesjonalna działalność pomocowa adresowana do ludzi borykających się z problemami funkcjonowania społecznego, liczy sobie nieco ponad jedno stulecie. Przeszła w tym czasie pewną ewolucję, co widać choćby po jej definicjach: tej wczesnej, przyjętej podczas Pierwszej Międzynarodowej Konferencji Pracy Socjalnej w Paryżu w 1928 roku oraz najnowszej, tzw. globalnej definicji pracy socjalnej, przyjętej w Melbourne w lipcu 2014 roku. Wedle tej pierwszej praca socjalna to „każde staranie nastawione na ulżenie cierpieniu z powodu ubóstwa, dla umożliwienia jednostkom i rodzinom odzyskania normalnych warunków życiowych, zapobieganie plagom społecznym, poprawę warunków socjalnych i życiowych społeczności za pomocą pracy z indywidualnymi przypadkami, pracy grupowej, nacisku społecznego na stanowienie prawa i na administrację oraz badań społecznych. Praca socjalna zatem obejmuje nie tylko pomoc społeczną, ubezpieczenie i działania społeczne, lecz także, do pewnego stopnia, higienę i edu-

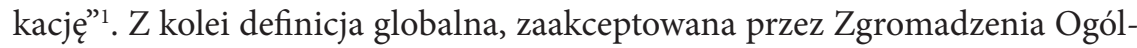

1 Cyt. za: J. Szmagalski, Jedna czy wiele? Rozwój koncepcji pracy socjalnej na świecie, Warszawa 2016, s. 146. 
ne Międzynarodowej Federacji Pracowników Socjalnych i Międzynarodowego Stowarzyszenia Szkół Pracy Socjalnej w lipcu 2014 roku mówi, iż „praca socjalna jest profesją opartą na praktyce i akademicką dyscypliną, która promuje zmianę społeczną i rozwój, społeczną spójność oraz empowerment i wyzwolenie ludzi. Głównymi zasadami pracy socjalnej są prawa człowieka, wspólnotowe poczucie odpowiedzialności i poszanowanie dla różnic. Praca socjalna oparta na własnych teoriach, naukach społecznych i humanistycznych oraz na rdzennej wiedzy angażuje ludzi i struktury społeczne do występowania przeciwko życiowym trudnościom i na rzecz poprawy ludzkiego bytu"2. Ta ewolucja w pojmowaniu pracy socjalnej jest świadectwem jej stopniowej profesjonalizacji i uzyskiwania przezeń znaczenia i zasięgu międzynarodowego.

O ile jednak sam termin „praca socjalna” oraz traktowanie jej jako działalności zawodowej/profesjonalnej ma rzeczywiście stosunkowo niedługą historię, to trzeba pamiętać, że jest ona konsekwencją wielowiekowych starań podejmowanych przez jednostki i instytucje, które chciały ulżyć niedoli ludzi społecznie upośledzonych, ubogich, niezaradnych życiowo, osamotnionych czy - jak mówimy współcześnie - wykluczonych i zagrożonych wykluczeniem społecznym. Przez wiele wieków działalność ta prowadzona była z motywacji religijnej i pod szyldem Kościoła. Opierając się na zasadzie miłości Boga i miłości bliźniego, określana jest jako posługa charytatywna czy też charytatywna funkcja Kościoła. Definiowana jest ona jako „działalność dobroczynna ludu Bożego wynikająca z Bożego przykazania miłości, adekwatna do potrzeb ludzi doświadczających materialnego lub duchowego ubóstwa, mająca na celu udzielanie im pomocy w zakresie podstawowych potrzeb egzystencjalnych i rozwoju osobowego"3.

Analogie pomiędzy pracą socjalną i działalnością charytatywną narzucają się jako coś niemalże oczywistego. W prezentowanym tekście chcę ukazać wybrane elementy wspólnej historii pracy socjalnej i charytatywnej, podobieństwo ich metod, a szczególnie zbieżność celu i zakresu działania.

\section{Od miłości bliźniego do professional helpers}

Jak zauważył Robert Bessell: „najwcześniejszy znany nam model pracy socjalnej, podobny do praktykowanego obecnie, został opisany w Dziejach Apostolskich"4. To odważne stwierdzenie pochodzi z podręcznika opublikowanego

Cyt. za: J. Szmagalski, Jedna czy wiele?..., dz. cyt., s. 160.

Zob. W. Przygoda, Charytatywna funkcja Kościoła, w: Leksykon teologii pastoralnej, red. R. Kamiński, W. Przygoda, M Fiałkowski, Lublin 2006, s. 130.

R. Bessel, Introduction to Social Work, London 1970, s. 12. 
w 1970 roku i dziś trudno byłoby uznać je za reprezentatywne dla głównego nurtu podręczników z zakresu pracy socjalnej. Tym bardziej warto pochylić się nad cechami owego „najwcześniejszego modelu” i spróbować dostrzec w nim podobieństwa do dzisiejszej, sprofesjonalizowanej i unaukowionej przecież, pracy socjalnej.

We wskazanej przez Bessella nowotestamentalnej księdze Dziejów Apostolskich znajduje się krótki opis ustanowienia siedmiu diakonów w pierwszej gminie chrześcijańskiej, w Jerozolimie. Według tego opisu członkowie wspólnoty dostrzegli problem wspierania potrzebujących jako coś istotnego dla codziennego praktykowania wiary. Dostrzegli też, że posługa ta musi być w jakiś sposób zorganizowana, ponieważ wzrastała liczba wiernych, a w konsekwencji coraz więcej było też potrzebujących. Powstała w tych okolicznościach instytucja diakonatu może być uznana za pierwowzór nowoczesnej pracy socjalnej, gdyż charakteryzowała się zadziwiająco profesjonalnym - jeśli można tu użyć takiego określenia - podejściem do procedur przyznawania pomocy. Jak przedstawia to badacz dziejów wczesnego chrześcijaństwa Adalbert G. Hamman, diakoni rozpoznawali potrzeby, badali wnikliwie każdą sytuację, wyszukiwali też sami potrzebujących, gdyż ci często wstydzili się prosić o pomoc. Można więc powiedzieć, że realizowany był już wówczas etap diagnozy sytuacji, czyli podstawowy element profesjonalnej pracy socjalnej. Następnie organizowane było odpowiednie wsparcie w postaci rozdawania posiłków, darów w naturze, a niekiedy także pieniędzy. W przypadku samotnych osób chorych diakon starał się znaleźć rodzinę lub osobę, która gotowa byłaby przyjąć kogoś takiego do swego domu i zaopiekować się nim, co można chyba bez wielkiego nadużycia potraktować jako pierwowzór współczesnych rodzinnych domów opieki. Działalność diakonów była do tego stopnia zinstytucjonalizowana, że w gminach prowadzono specjalne księgi, w których odnotowywano, komu i w jakim zakresie udzielana była pomoc ${ }^{5}$. I tak co najmniej do czasów reformacji historia pracy socjalnej była w Europie właściwie tożsama $\mathrm{z}$ historią kościelnej działalności dobroczynnej.

Przykazania miłości Boga i bliźniego nazwać można „podstawowym prawem chrześcijańskiej caritas" ${ }^{\prime}$, z czego wynika, że każdy rodzaj działalności charytatywnej musi być jednocześnie działaniem Miłości, rozumianej na sposób ewangeliczny. W kontekście tak sformułowanego podstawowego prawa działalności charytatywnej należy postawić pytanie, w jaki sposób przykazanie miłości bliźniego może być zrealizowane praktycznie. Konkretne przykłady na to

Zob. A. G. Hamman, Życie codzienne pierwszych chrześcijan, Warszawa 1990, s. 202-204.

6 J. Ernst, Caritas. Biblisch, w: Neues Handbuch theologischer Grundbegriffe, Hrsg. P. Eicher, Bd. 1, München 1991, s. 245. 
znajdują się również w Nowym Testamencie. Takim najbardziej chyba znanym jest Przypowieść o miłosiernym Samarytaninie (Łk 10, 25-37). Chrystus ukazuje w niej los człowieka napadniętego i ograbionego przez zbójców. Przechodzący obok kapłan, a potem lewita, pozostawili napadniętego, nie udzieliwszy mu pomocy, choć po osobach tego stanu należałoby oczekiwać jakiejś wrażliwości na ludzką krzywdę. Pomógł natomiast przechodzący tamtędy Samarytanin, człowiek obcy, mający swoje sprawy, zapewne bardzo się spieszący. Czyn Samarytanina i jego kontekst pokazuje, że w przykazaniu miłości bliźniego nie chodzi o jakąś abstrakcję, ale o „bezpośredni akt pomocy w konkretnej sytuacji”’. Przypowieść ta wyjaśnia zarazem, kogo należy uważać za bliźniego. Jest nim mianowicie każdy człowiek, zwłaszcza ten, który w danym momencie potrzebuje wsparcia. Tym, co się liczy najbardziej, jest fakt, że jest on człowiekiem, a co za tym idzie - także nosicielem obrazu samego Boga. Prawdziwa miłość bliźniego musi się więc kierować do wszystkich ludzi bez wyjątku, ponieważ i Bóg kocha wszystkich bez wyjątku. Chrześcijańska miłość bliźniego jest więc „nie tylko odpowiedzią na potrzebę człowieka, ale też odpowiedzią na Bożą miłość", jak to trafnie wyraził Richard Völkl ${ }^{8}$.

Nieco uwagi poświęcić należy św. Wincentemu á Paulo, albowiem określany jest on mianem twórcy katolickiego systemu opieki społecznej ${ }^{9}$. Od 1617 roku głosił misje i zakładał bractwa miłosierdzia w wielu diecezjach francuskich, ale w 1621 roku, wskutek zetknięcia się z rzeszą ludzi ubogich w Mâcon, doszedł do wniosku, że działalność bractw przy parafiach to zdecydowanie za mało w obliczu tych problemów. Powołał zatem dwa bractwa: męskie do opieki nad biednymi i żeńskie do opieki nad chorymi. Praktyczna działalność pomocowa poprzedzona została dokładną diagnozą sytuacji, z której wynikało, że w mieście i okolicy około trzystu osób żyje w skrajnym ubóstwie. Utworzony został fundusz pomocowy, który składał się z dobrowolnych ofiar mieszkańców, jednego procenta $z$ opłat skarbowych urzędów publicznych i kwest przeprowadzanych przez bractwa. Żebracy mieli gromadzić się każdej niedzieli w kościele św. Nazariusza, gdzie najpierw mieli obowiązek uczestniczyć we Mszy Świętej, a potem mogli otrzymywać chleb i zapomogi pieniężne. Co tydzień odnawiano spisy ubogich, dyskretną opieką otaczano także ubogich wstydliwych, zaś zdolnych do pracy wspierano poprzez dodatki do ich skromnych zarobków. Ci, którzy żebrali po kryjomu mieli być karani ${ }^{10}$. Założone przez Wincentego á Paulo

J. Ernst, Caritas. Biblisch, w: Neues Handbuch..., dz. cyt., s. 247.

R.Völkl, Nächstenliebe. Die Summe der christlichen Religion?, Freiburg i.Br. 1987, s. 141.

9 Zob. J. Radwan-Pragłowski, K. Frysztacki, Miłosierdzie i praktyka. Społeczne dzieje pomocy człowiekowi, Katowice 2009, s. 211.

10 Zob. L. Mezzardi, Wincenty á Paulo. Miłosierdzie i świętość, Kraków 2010, s. 85-86. 
Zgromadzenia Księży Misjonarzy (lazarystów) i Sióstr Miłosierdzia (bardziej znanych jako szarytki) na trwałe wpisały się w obraz kościelnej działalności dobroczynnej w wielu krajach.

Jako szczególnie znaczące wymienić należy Arcybractwo Miłosierdzia, którego założycielem był jezuita Piotr Skarga. Przebywając we Włoszech, zapoznał się on z działalnością charytatywną bractw pobożnych i próbował przenieść tę ideę na grunt polski. Najpierw w Wilnie, a później - już w pełni udanie - w Krakowie. Arcybractwo Miłosierdzia zawiązało się w 1584 roku, stawiając sobie za cel główny pomoc ubogim wstydzącym się żebrać. Jak zwracają uwagę Janusz Radwan-Pragłowski i Krzysztof Frysztacki, ustawa Arcybractwa była dowodem znakomitego rozumienia problemu i wybitnych umiejętności organizacyjnych księdza Skargi. Dość precyzyjnie ustalona była bowiem struktura stowarzyszenia i dokładnie opisane czynności związane z poszczególnymi funkcjami. Takim nowoczesnym - z dzisiejszej perspektywy - rozwiązaniem było choćby wprowadzenie funkcji wizytatorów i szafarzy. Obowiązkiem tych pierwszych było sprawdzanie faktycznej sytuacji osób, zgłoszonych jako potrzebujących pomocy. Szafarzom zaś przypadła rola przekazywania potrzebującym pieniędzy przyznanych przez braci i systematyczne składanie dokładnych sprawozdań z udzielanego wsparcia ${ }^{11}$. Nowoczesność opisanego sposobu działania polega głównie na tym, że kluczem do skutecznej i efektywnej pomocy jest przeprowadzenie diagnozy i oceny konkretnego przypadku. Wspomniani wizytatorzy to - jak się wydaje - prekursorzy współczesnych profesjonalnych pracowników socjalnych, których rolą jest między innymi właśnie diagnoza sytuacji potencjalnego świadczeniobiorcy i kwalifikowanie do określonych form pomocy.

Postacią niezwykle ważną dla rozwoju pracy socjalnej i pomocy społecznej jest szkocki pastor Thomas Chalmers, nazywany przez niektórych autorów „ojcem pracy socjalnej”"12. Krytykował on system oparty na tzw. prawie o ubogich i w 1819 lub 1822 roku (źródła podają różne daty) przeprowadził swoisty eksperyment, polegający na zorganizowaniu pomocy w oparciu o cztery zasady: pomoc samym sobie, pomoc krewnych, wzajemna pomoc pomiędzy ubogimi i w ostateczności pomoc ze strony bogatych ${ }^{13}$. Zanim jednak to nastąpiło, odwiedził każdą rodzinę w jedenastotysięcznej parafii Tron w Glasgow (gdzie pracował od 1815 roku), aby poznać ich warunki życia i stwierdził, że znaczna część z nich żyła ze wsparcia „prawa o ubogich”, zdemoralizowana i pozostawiona sama sobie. Stwierdził, że stan ten nie zmieni się, dopóki pomoc będzie

\footnotetext{
11 Por. J. Radwan-Pragłowski, K. Frysztacki, Miłosierdzie i praktyka..., dz. cyt., s. 220.

12 J. Radwan-Pragłowski, K. Frysztacki, Miłosierdzie i praktyka..., dz. cyt., s. 309.

13 Zob. J. Szmagalski, Jedna czy wiele?..., dz. cyt., s. 16.
} 
administrowana przez władze publiczne wedle dotychczasowych zasad ${ }^{14}$. Skłonił więc władze miasta do utworzenia nowej parafii, którą podzielił na 25 rejonów, zamieszkiwanych przez ok. 50 rodzin każdy. Za każdy rejon odpowiedzialny był odpowiednio przeszkolony diakon, którego praca polegała na rozpoznaniu indywidualnych warunków życia i rzeczywistych potrzeb osób i rodzin oraz na dobraniu właściwej formy wsparcia ${ }^{15}$. Mamy tu do czynienia z kontynuacją i rozwinięciem znanej i praktykowanej od początków chrześcijaństwa instytucji diakonatu, dostosowanej do zmieniających się warunków społecznych i ekonomicznych.

Pisząc o nowatorskich rozwiązaniach, bazujących jednak na religijnie motywowanym miłosierdziu wobec potrzebujących, wspomnieć trzeba o chrześcijańskich konotacjach ruchu settlements. Jego istotą było działanie w środowisku, przekraczanie granic pomiędzy warstwami uprzywilejowanymi i społecznie zdegradowanymi, aktywizacja i integracja społeczności lokalnych w miastach, w szczególnie trudnych dzielnicach. Settlementy oznaczały zatem „ściślej rozumianą pracę socjalną" ${ }^{\prime 6}$, bardzo ambitny projekt, który ukierunkowany był nie na doraźne załagodzenie problemu ubóstwa i marginalizacji, ale na zmianę społeczną. Twórcą pierwszego settlement był pastor anglikański Samuel Augustus Barnett, który w 1873 roku objął funkcję proboszcza w parafii św. Judy w Whitechapel. Była ona zlokalizowana w najuboższej i słynącej z wysokiej przestępczości londyńskiej dzielnicy East End. Zgodnie z zamysłem Barnetta, settlement miał być miejscem zapewniającym edukację i godny wypoczynek biednych mieszkańców miast, a także obiektem badań naukowych mających na celu poprawę warunków życia tych ludzi. Stąd też wynikała ścisła współpraca ze studentami i pracownikami naukowymi uniwersytetów Oxford i Cambridge. Pierwsza tego typu placówka została otwarta w 1884 roku, a w jej nazwie - Toynbee Hall - uczczono postać Arnolda Toynbee. Był on tutorem w oksfordzkim Balliol College i przez wiele lat osobiście angażował się w pracę charytatywną wśród mieszkańców Wschodniego Londynu. Był orędownikiem chrześcijańskiego socjalizmu i zmarł przedwcześnie z powodu - jak się przypuszcza - przemęczenia organizmu właśnie działalnością charytatywną ${ }^{17}$. Ani Toynbee, ani tym bardziej Barnett nie odcięli się od chrześcijańskiej inspiracji w działaniu, w znacznym jednak stopniu przestawili ją na zupełnie inne tory, w kierunku swoistej aktywizacji beneficjentów wsparcia.

${ }_{14}$ A. F. Young, E. T. Ashton, British Social Work in the Nineteenth Century, London 1967, s. 70 .

15 J. Szmagalski, Jedna czy wiele?..., dz. cyt., s. 16.

16 J. Radwan-Pragłowski, K. Frysztacki, Miłosierdzie i praktyka..., dz. cyt., s. 422.

17 Por. J. Szmagalski, Jedna czy wiele?..., dz. cyt., s. 30-31. 
Pojawienie się profesjonalnych służb społecznych było zatem wynikiem wielowiekowej ewolucji działalności pomocowej, $\mathrm{Z}$ oczywistych względów przez większość tego czasu była to działalność związana ze wspólnotami chrześcijańskimi i silnie nacechowana praktyczną realizacją idei miłości bliźniego. Fakt, że na przełomie XIX i XX wieku zaczęło funkcjonować pojęcie pracy socjalnej i zaczęto kształcić do zawodowego pomagania, był także ukoronowaniem fenomenu wieku filantropów, jak określili go Radwan-Pragłowski i Frysztacki. Zauważyli oni bowiem, że na gruncie dziewiętnastowiecznej filantropii „spotkali się działacze natchnieni duchem rewolucji francuskiej, nowego rozumienia religii katolickiej, obowiązkiem chrześcijańskim i miłością bliźniego czy wreszcie ideami socjalizmu"18. Wszyscy oni przyczynili się do powstania zawodu pracownika socjalnego i do stworzenia podwalin welfare state. Działalność charytatywna okazuje się jednak nadal potrzebna, choć oczywiście zmieniają się jej formy i metody. Ewoluują także problemy społeczne, z którymi zmagają się i pracownicy socjalni i działacze charytatywni, ale jedni i drudzy mają jeszcze wielu potencjalnych adresatów swojej aktywności.

\section{Nowoczesna działalność charyłaływna - profesjonalna chrześcijańska praca socjalna?}

Ograniczając się do polskich realiów można stwierdzić, iż katalog potencjalnych adresatów pracy socjalnej zawarty jest w ustawie o pomocy społecznej, ponieważ pracownicy socjalni są tymi, którzy kwalifikują do świadczeń z systemu pomocy społecznej. Zgodnie z przepisami ustawowymi pomoc społeczna udzielana jest osobom i rodzinom dotkniętym w szczególności ubóstwem, sieroctwem, bezdomnością, bezrobociem, niepełnosprawnością, długotrwałą lub ciężką chorobą, przemocą w rodzinie. Adresowana jest ponadto do ofiar handlu ludźmi, osób wymagających ochrony w sytuacji macierzyństwa lub wielodzietności, bezradnych w sprawach opiekuńczo-wychowawczych i prowadzenia gospodarstwa domowego, zwłaszcza w rodzinach niepełnych lub wielodzietnych. Odbiorcami pomocy społecznej mogą być też cudzoziemcy, którzy uzyskali w Rzeczypospolitej Polskiej status uchodźcy, ochronę uzupełniającą lub zezwolenie na pobyt czasowy. Wsparcie oferowane jest także osobom mającym trudności w przystosowaniu do życia po zwolnieniu z zakładu karnego, uzależnionym od alkoholu i narkotyków oraz doświadczonym zdarzeniem losowym, sytuacją kryzysową, klęską żywiołową lub ekologiczną ${ }^{19}$. Ten stosun-

18 J. Radwan-Pragłowski, K. Frysztacki, Miłosierdzie i praktyka..., dz. cyt., s. 294.

19 Ustawa z dnia 12 marca 2004 roku o pomocy społecznej, Dz. U. z 2016 r. Nr 0, poz. 930, art. 7. 
kowo obszerny, a przecież niezamknięty katalog, w zasadzie w całości pokrywa się z listą typowych odbiorców świadczonej i dziś działalności charytatywnej. Trzeba przy tym zauważyć, że skojarzenie działalności charytatywnej na przykład Kościoła katolickiego z rozdawnictwem darów przy parafiach jest już dawno nieaktualne. Wprawdzie w okresie stanu wojennego czy też w początkowych latach transformacji ustrojowej był to główny obszar działalności, ale instytucje kościelne dość szybko dostrzegły nowe możliwości działania. Zostały one stworzone przez przepisy, najpierw ustawy o pomocy społecznej z 1990 roku (podtrzymane w ustawie z 2004 roku), a następnie ustawy o działalności pożytku publicznego i o wolontariacie z 2003 roku. Struktury charytatywne, zwłaszcza diecezjalne Caritas dość szybko odnalazły się w tych zmienionych warunkach.

Swoistym znakiem rozpoznawczym działalności charytatywnej w Polsce były w pierwszej połowie lat 90 . XX wieku Stacje Opieki Caritas. Powstały one najpierw w diecezji opolskiej, dzięki wydatnej pomocy finansowej rządu niemieckiego i niemieckiej Caritas. Program Stacji Opieki zainicjowany został w roku 1992 i był „nowoczesną formą opieki pielęgniarskiej nad człowiekiem chorym i wymagającym pielęgnacji w domu"20. Stanowił on konkretną odpowiedź na problemy i niedomagania ówczesnej służby zdrowia, szczególnie w zakresie pomocy osobom mieszkającym na terenach wiejskich, o bardzo ubogiej infrastrukturze medycznej i komunikacyjnej. Z czasem projekt rozprzestrzenił się na cały kraj i bez przesady można stwierdzić, iż stworzona została w ten sposób możliwość dostępu do usług pielęgniarskich wielu ludziom, którzy w żaden inny sposób nie mogli być objęci tego rodzaju opieką. Warto także zauważyć, że właśnie stacje opieki okazały się w praktyce pierwszym projektem Caritas, który mógł otrzymać wsparcie finansowe ze środków publicznych ${ }^{21}$. Skala tego przedsięwzięcia była tak duża, że bez wsparcia samorządów lokalnych nie udałoby się go zrealizować, mimo środków pozyskanych z zagranicy.

Stosunkowo szybko, bo już w 1996 roku adresatem kościelnej działalności dobroczynnej stali się cudzoziemcy, przybywający do Polski w poszukiwaniu lepszych warunków egzystencji. W większości wypadków byli do przybysze z krajów byłego Związku Radzieckiego. Wiosną 1996 roku Caritas Archidiecezji Białostockiej powołała do istnienia Biuro Informacji dla Migrantów i Uchodźców. Celem biura od początku jest przekazywanie cudzoziemcom niezbędnych informacji (w zrozumiałym dla nich języku), poradnictwo prawne, pomoc materialna i wsparcie duchowe. W pierwszych latach działalności z usług biura skorzystali przede wszystkim obywatele Armenii. Charakterystyczną cechą pracy

20 A. Drechsler, Odpowiedzialni za miłość. Opolska Caritas w latach 1945-2005, Opole 2007, s. 117.

${ }^{21}$ Zob. A. Drechsler, Odpowiedzialni za miłość..., dz. cyt., s. 119. 
placówki jest udzielanie pomocy wszystkim cudzoziemcom znajdującym się w trudnej sytuacji życiowej, niezależnie od narodowości, wyznania, rasy i statusu formalnego. W roku 2004 biuro przekształcone zostało w Centrum Pomocy Migrantom i Uchodźcom Caritas Archidiecezji Białostockiej ${ }^{22}$. Podobne Centra zaistniały również w Lublinie, Warszawie i Zgorzelcu.

W roku 2001 rozpoczęła się działalność Caritas w dziedzinie pomocy ofiarom handlu ludźmi, szczególnie kobietom zmuszanym do prostytucji. Przygotowany został projekt pod nazwą „Program Przeciwdziałania Przymuszonej Prostytucji”, którego celem było utworzenie w pięciu miastach w Polsce specjalnych punktów informacyjnych, świadczących bezpośrednią pomoc kobietom zmuszanym do prostytucji. Punkty udzielają informacji telefonicznej z zachowaniem pełnej anonimowości ${ }^{23}$. Aktywne w tej dziedzinie jest także posługujące się nowatorskimi metodami „Stowarzyszenie Po MOC dla Kobiet i Dzieci im. Marii Niepokalanej", które powstało w 2001 roku z inicjatywy siostry Anny Bałchan. Interesujące jest, że organizacja ta działa na podstawie Prawa o stowarzyszeniach oraz Ustawy o działalności pożytku publicznego i o wolontariacie i nie określa się wprost jako stowarzyszenie katolickie. Zostało ono jednak założone z inicjatywy siostry zakonnej, a swoją siedzibę ma w Domu Prowincjalnym Sióstr Maryi Niepokalanej w Katowicach ${ }^{24}$. Stowarzyszenie posługuje się w swojej pracy metodą streetworkingu, która w tym przypadku polega na wchodzeniu w środowisko osób zajmujących się prostytucją, nawiązaniu z nimi kontaktu i poinformowaniu o istniejącej ofercie pomocowej. Stowarzyszenie prowadzi też punkt konsultacyjny, w którym odbywają się indywidualne spotkania z profesjonalistami udzielającymi wsparcia psychologicznego i terapeutycznego oraz pomocy prawnej i zawodowej. Poradnictwo prowadzone jest także z wykorzystaniem Internetu. Punkt Konsultacyjny przyjmuje kobiety, które znalazły się w trudnej sytuacji życiowej lub czują się skrzywdzone w jakikolwiek sposób. W całodobowym Ośrodku Rehabilitacyjno-Wychowawczym natomiast oferowane jest schronienie kobietom i kobietom $\mathrm{z}$ dziećmi, znajdującym się w sytuacji kryzysowej. Ponadto Stowarzyszenie zajmuje się prowadzeniem kampanii społecznych (np. Stop Niewolnictwu), organizowaniem warsztatów dla młodzieży oraz szkoleń dla osób angażujących się w pracę na rzecz ofiar handlu ludźmi i przymuszonej prostytucji ${ }^{25}$.

22 Zob. Być głosem ubogich: 15 lat Caritas w Polsce, Warszawa 2004, s. 30-31; zob. także: B. Cieślińska, Imigranci w Białymstoku. Pierwsze doświadczenia nowej placówki Caritas, „Białostocczyzna” 1996, nr 3, s. 90-93.

23 Zob. Być głosem ubogich..., dz. cyt., s. 9-10.

24 Statut „Stowarzyszenia Po MOC dla Kobiet i Dzieci im. Marii Niepokalanej”, tekst jednolity, art. 2 i 4, http://www.po-moc.pl/materialy/_upload/file/Statut/Statut_Stowarzyszenia_Po_MOC_20_03_2010.pdf (16.12.2016).

25 Więcej informacji o funkcjonowaniu Stowarzyszenia na http://www.po-moc.pl. 
Bardzo interesującym pomysłem na pomoc osobom bezrobotnym okazały prowadzone przez Caritas Biura Aktywizacji Bezrobotnych oparte na nowatorskiej w polskich warunkach metodzie towarzyszenia. Polega ona na „indywidualnym podejściu do sytuacji bezrobotnego, w czasie, jaki dana osoba potrzebuje, aby na nowo odzyskać wiarę w siebie, nawiązywać relacje z innymi i włączyć się aktywnie w życie społeczne i zawodowe poprzez podjęcie zatrudnienia"26. Co bardzo istotne, realizacja tej idei pokazała też zdolność instytucji kościelnych do ubiegania się o wsparcie z funduszy unijnych i - co za tym idzie - poddania się wymaganym procedurom konkursowym, kontrolnym i ewaluacyjnym. Pierwszy projekt wykorzystujący tę metodę wspierania bezrobotnych zrealizowany został w okresie od 1 września 2002 roku do 30 września 2003 roku i sfinansowany był z PHARE ACCESS 2000. Projekt objął cztery Caritas diecezjalne: warmińską, lubelską, toruńską i kielecką. Krajowymi partnerami Caritas w projekcie były Urzędy Pracy, zaś partnerem zagranicznym była Secours Catholique - Caritas France. Projekt ten uznać można za istotny krok ku profesjonalizacji działalności Caritas w Polsce. Jego realizacja przyczyniła się do wzmocnienia pozycji Caritas jako partnera dla administracji rządowej i samorządowej oraz innych organizacji trzeciego sektora ${ }^{27}$.

Dobrym świadectwem szybkiego reagowania kościelnej dobroczynności na nowe możliwości działania jest utworzenie w październiku 2004 roku w strukturach Caritas Kieleckiej Centrum Integracji Społecznej. Było ono czwartym w Polsce, ale pierwszym utworzonym przez podmiot pozarządowy. Uczestnicy Centrum otrzymali między innymi możliwość pracy w warsztatach: krawieckim, stolarskim, remontowo-budowlanym oraz w brygadzie porządkowej ${ }^{28}$. W ten sposób kościelne struktury charytatywne włączyły się w działania, które wchodzą w zakres aktywnej czy też aktywizującej polityki społecznej ${ }^{29}$ i przeciwdziałanie problemom wykluczenia społecznego. Powiększa się także liczba spółdzielni socjalnych prowadzonych pod szyldem Caritas i innych podmiotów charytatywnych. Osoby długotrwale bezrobotne, niepełnosprawne, bezdomne czy uzależnione mają dzięki nim możliwość podjęcia pracy, czego skutkiem jest nie tylko otrzymywanie wynagrodzenia, ale również odzyskanie poczucia przydatności w społeczeństwie, nawiązywanie relacji z innymi itp.

26 E. Błyskun, M. Titaniec, Proces towarzyszenia osobie bezrobotnej, w: Schody na rynek pracy. Vademecum pracy z osobami bezrobotnymi, Warszawa 2005, s. 24.

27 Zob. M. Titaniec, Opis projektu „Aktywizacja personalna, zawodowa i społeczna osób długotrwale bezrobotnych, zagrożonych marginalizacja, „Roczniki Naukowe Caritas” 2002, nr 6, s. 169-170.

28 Zob. Być głosem ubogich..., dz. cyt., s. 116.

29 Szerzej na temat aktywnej polityki społecznej zob. M. Rymsza, Aktywizacja w polityce społecznej. W stronę rekonstrukcji europejskich welfare states?, Warszawa 2013. 


\section{Zakończenie}

Praca socjalna jako profesjonalna działalność pomocowa wyrosła $\mathrm{z}$ bardzo długiej tradycji pomagania zakorzenionej $\mathrm{w}$ inspiracjach duchowych/religijnych, sięgających odległej starożytności. Szczególną postać instytucjonalną działalność ta przybrała wraz z pojawieniem się chrześcijaństwa i idei caritas jako czynnej miłości bliźniego. Po wiekach swoistego monopolu religijnej dobroczynności pojawiła się zawodowa praca socjalna, wykonywana przez wykwalifikowany personel wyspecjalizowanych instytucji działających w oparciu o dość szczegółowe przepisy i normy funkcjonowania. Spowodowało to - w mniejszym lub większym stopniu - scedowanie na państwo odpowiedzialności za los ludzi w potrzebie. Niewątpliwie jednak działalność charytatywna nie straciła na znaczeniu i w istotny sposób uzupełnia pracę socjalną realizowaną przez państwowe służby społeczne. Pracę socjalną i działalność charytatywną łączy bowiem nie tylko wspólna historia, ale także cel i zakres działania. W obu przypadkach chodzi wszak o niesienie wsparcia osobom potrzebującym, niezaradnym życiowo, zagubionym. Obie powinny realizować się w relacji międzyosobowej, w autentycznym spotkaniu pomagającego i wspomaganego. I choć w odniesieniu do pracy socjalnej podkreślany jest jej profesjonalizm, to również działalność charytatywna bardzo zmieniła swoje oblicze. Potrafi szybko reagować na zmiany warunków działania i pojawiające się nowe problemy oraz poszukiwać innowacyjnych metod pomagania. W tym sensie zarówno zawodowa praca socjalna, jak i działalność charytatywna kroczą wspólną drogą do człowieka w potrzebie, są sprzymierzeńcami w dobrym dziele.

\section{Bibliografia}

Bessel R., Introduction to Social Work, London 1970.

Błyskun E., Titaniec M., Proces towarzyszenia osobie bezrobotnej, w: Schody na rynek pracy.

Vademecum pracy z osobami bezrobotnymi, Warszawa 2005.

Być głosem ubogich: 15 lat Caritas w Polsce, Warszawa 2004.

Cieślińska B., Imigranci w Białymstoku. Pierwsze doświadczenia nowej placówki Caritas, „Białostocczyzna” 1996, nr 3.

Drechsler A., Odpowiedzialni za miłość. Opolska Caritas w latach 1945-2005, Opole 2007.

Ernst J., Caritas. Biblisch, w: Neues Handbuch theologischer Grundbegriffe, Hrsg. P. Eicher, München 1991.

Hamman A. G., Życie codzienne pierwszych chrześcijan, Warszawa 1990.

Mezzardi L., Wincenty á Paulo. Miłosierdzie i świętość, Kraków 2010. 
Przygoda W., Charytatywna funkcja Kościoła, w: Leksykon teologii pastoralnej, red. R. Kamiński, W. Przygoda, M. Fiałkowski, Lublin 2006.

Radwan-Pragłowski J., Frysztacki K., Miłosierdzie i praktyka. Społeczne dzieje pomocy człowiekowi, Katowice 2009.

Rymsza M., Aktywizacja w polityce społecznej. W strone rekonstrukcji europejskich welfare states?, Warszawa 2013.

Szmagalski J., Jedna czy wiele? Rozwój koncepcji pracy socjalnej na świecie, Warszawa 2016.

Titaniec M., Opis projektu „Aktywizacja personalna, zawodowa i społeczna osób długotrwale bezrobotnych, zagrożonych marginalizacją, „Roczniki Naukowe Caritas” 2002, nr 6.

Völkl R., Nächstenliebe. Die Summe der christlichen Religion?, Freiburg i. Br. 1987.

Young A. F., Ashton E. T., British Social Work in the Nineteenth Century, London 1967.

Ustawa z dnia 12 marca 2004 roku o pomocy społecznej, Dz. U. z 2016 r. Nr 0, poz. 930.

Statut „Stowarzyszenia Po MOC dla Kobiet i Dzieci im. Marii Niepokalanej”, tekst jednolity, http://www.po-moc.pl/materialy/_upload/file/Statut/Statut_Stowarzyszenia_Po_ MOC_20_03_2010.pdf (16.12.2016). 
4/ Uniwersytet Papiesk

Tê. Jana Pawła I 


\section{CZĘŚĆ 2}

Tożsamość służb socjalnych: aksjologia i metody pomagania 
4/ Uniwersytet Papiesk

Tê. Jana Pawła I 